\title{
Methodical Approach to Determining the Points of Economic Growth in the Center and Peripheral Rates in Ukraine
}

\author{
Kozyireva Olena \\ Department of management and administraton \\ National University of Pharmacy \\ Kharkiv, Ukraine \\ yakakos74@gmail.com \\ http://orcid.org/0000-0002-2014-4584
}

Olkhovska Angela

\author{
Department of pharmaceutical management \\ and marketing \\ National University \\ of Pharmacy \\ Kharkiv, Ukraine \\ angelika.olkhovskaya@gmail.com \\ http://orcid.org/0000-0002-0237-5741
}

\author{
Garafonova Olga \\ Department of management \\ Kyiv National Economics University named \\ after Vadym Hetman \\ Kyiv, Ukraine \\ ogarafonova@ukr.net \\ http://orcid.org/0000-0002-4740-7057
}

\author{
Sumets Olehandr \\ Department of management and \\ administraton National University \\ of Pharmacy \\ Kharkiv, Ukraine \\ sumets.alehander@gmail.com \\ http://orcid.org/0000-0002-7116-3857
}

\begin{abstract}
The article summarizes the existing approaches to studying the processes of economic growth within the problematic field of economic and social sciences. On this basis, the priority components of the country's regions economic growth, including economic, technological, resource, spatial, territorial, state and tax-budget, are determined. It is proved that for the purpose of modeling the growth processes in the center and peripheral rates in the Ukrainian regions it is expedient to use the theories of the economic and cumulative growth poles. The logical scheme concerning the relationship between the theories of growth, which includes the economic core, the pole of growth, the axis of growth, the basic elements, the area of advance growth, agglomeration, the city, industry, enterprise, territorial and industrial complex, the pole of competitiveness, cluster, educational institution, research institutes, is developed. A two-dimensional matrix for positioning regions in the plane "integral estimations of economic growth and development factors" is proposed, allowing to identify the status of each region in terms of using its potential economic growth factors and achieved level of economic development.
\end{abstract}

Keywords - economic development, regional development, center and peripheral relations, points of economic growth, poles of economic growth, cumulative growth.

\section{INTRODUCTION.}

A number of semi-peripheral and peripheral regions require state support aimed at equalizing the trends of social and economic development of leadind and problem regions, as well as the introduction of such a mechanism to promote economic activity aimed at economic growth. Implementation of these measures requires appropriate methodological support.

The goal of the article id to imply prompting the research results of determination the problem concerning consolidated assessment of socio-economic development of Ukrainian regions.

\section{StATEMENT OF THE PROBLEM}

However, reasoning the topical approach to the determination of the level of socio-economic development of country regions requires in-depth development that in its turn determines the relevance of this article.

Research on the problems of regions' economic growth is closely related to formation of the state support system for regional development and is at the intersection of various social and natural sciences problematic issues (Fig. 1).

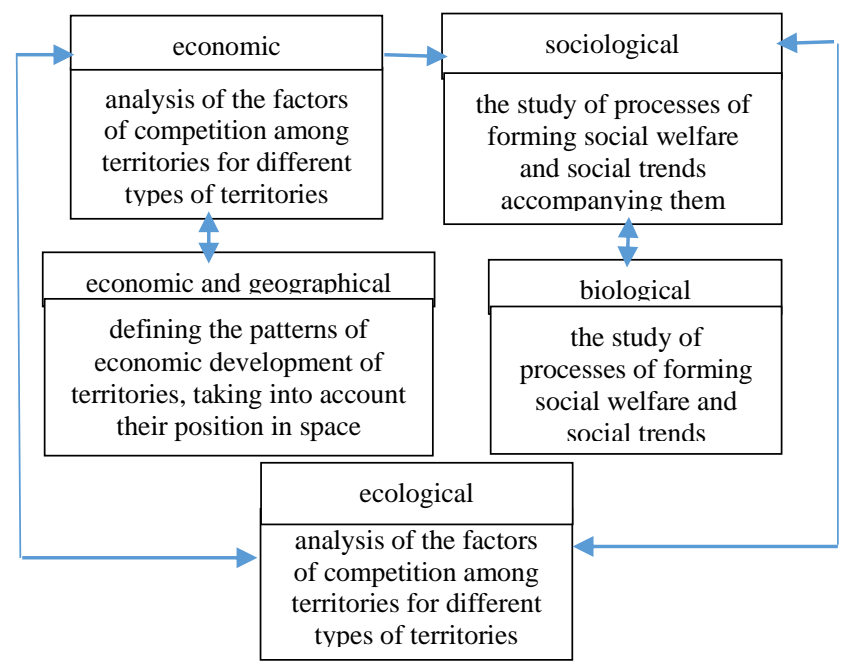

Fig. 1. Approaches to research on the processes of economic growth within the problematic issues of various sciences

The multifaceted nature of process in question is confirmed by a large number of interpretations concerning 
the essence and content of this concept. Thus, most authors interpret economic growth as an increase, an increase in the indicators of economic development within a certain period of time [1, 2, 3]. Many scientists [4, 5, 6] etc. make an emphasis on the opportunities and potential for economic growth.

Priority components of economic growth include: resource, spatial and territorial, economic, technological, state and tax-budget components. The above components allow to determine two directions of its interpretation in the semantic field of the theory of economic growth poles (Fig. 2).

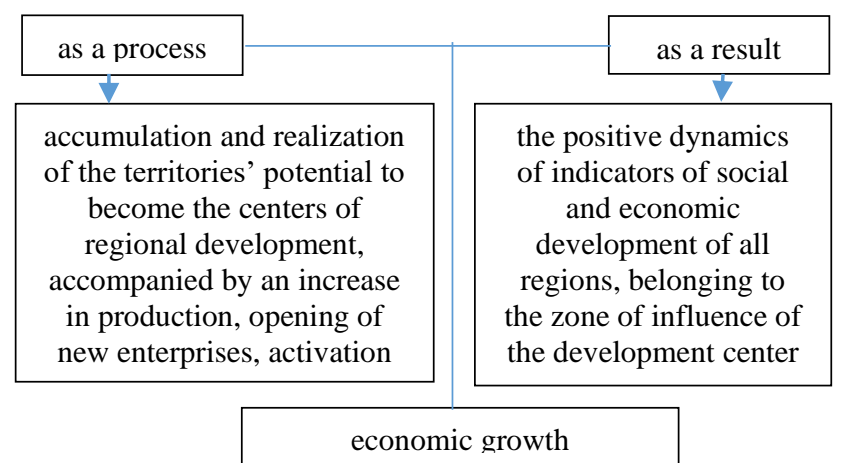

Fig. 2. Interpretation of the concept of "economic growth" in the semantic field of the theory of economic growth poles

Concentration of growth poles within certain territories turns them into development centers.

The survey conducted allows to determine the possibilities of using the achievements of the theory of growth poles to solve problems of developing the country's regions on the basis of priority goals (Table 1).

Thus, the theory of growth poles explains the processes of stimulating the social and economic development of regions through creating development centers in their territories with innovative high-tech industries.

TABLE I. ANALYSIS OF THE POSSIBILITY OF APPLYING THEORETICAL AND PRACTICAL INSTRUMENTATION OF POLES GROWTH THEORY FOR INVESTIGATING INORRUPTION OF REGIONAL DEVELOPMENT

\begin{tabular}{|l|l|}
\hline \multicolumn{1}{|c|}{$\begin{array}{c}\text { Objectives of regional } \\
\text { development }\end{array}$} & $\begin{array}{l}\text { Possibilities of their solution using } \\
\text { the theory of growth poles }\end{array}$ \\
\hline $\begin{array}{l}\text { Stimulating the social and } \\
\text { economic development of the } \\
\text { region as a whole and its separate } \\
\text { regions }\end{array}$ & $\begin{array}{l}\text { Introducing propulsive and } \\
\text { auxiliary industries in areas not } \\
\text { necessarily belonging to the } \\
\text { administrative center of the region }\end{array}$ \\
\hline $\begin{array}{l}\text { Improving the spatial and } \\
\text { economic structure of the region }\end{array}$ & $\begin{array}{l}\text { Formation of alternative centers of } \\
\text { economic growth in semi-peripheral } \\
\text { areas, reducing the burden on the } \\
\text { administrative center }\end{array}$ \\
\hline $\begin{array}{l}\text { Reducing unemployment, } \\
\text { creating new jobs }\end{array}$ & $\begin{array}{l}\text { Introducing new innovations of } \\
\text { economic activity types in the } \\
\text { development center and auxiliary } \\
\text { industries in semi-peripheral or } \\
\text { peripheral regions }\end{array}$ \\
\hline $\begin{array}{l}\text { Stimulation of innovative } \\
\text { development of the region and its } \\
\text { separate regions }\end{array}$ & $\begin{array}{l}\text { The introduction of propulsion, } \\
\text { innovation-oriented types of } \\
\text { economic activity }\end{array}$ \\
\hline
\end{tabular}

In the theory of cumulative growth one operates with the following concepts: growth point, growth pole, economic core, pole of competitiveness, zone of outstripping development, development axis, and others.
In table 2, the essence of some of the above concepts found in the scientific literature is provided.

TABLE II. THE SCIENTISTS' POINTS OF VIEW ON THE ESSENCE OF SOME CONCEPTS RELATING TO THE THEORY OF CUMULATIVE GROWTH

\begin{tabular}{|c|c|}
\hline Author/Refernce & Essence of the concept \\
\hline F. Perru [7] & $\begin{array}{l}\text { The growth pillar implies the } \\
\text { dynamically developing sectors of } \\
\text { economy, where the "impetus for } \\
\text { development", affecting the territorial } \\
\text { structure of the region, is concentrated. }\end{array}$ \\
\hline Zh. Budvil [8 ] & $\begin{array}{l}\text { The growth pole is a geographical } \\
\text { agglomeration of economic activity or a } \\
\text { set of cities that has a complex of rapidly } \\
\text { developing industries }\end{array}$ \\
\hline H. Lausen [9] & $\begin{array}{l}\text { The growth pillar is the regional } \\
\text { business unit associated with the export } \\
\text { sector of the region's economy located in } \\
\text { one or more geographic shrubs } \\
\text { (concentrations) of the region }\end{array}$ \\
\hline T. Lashcheva [10] & $\begin{array}{l}\text { The point of economic growth - the } \\
\text { economic (economic) entity, branch or } \\
\text { type of activity, which can, as a result of } \\
\text { activation, be able to diversify and } \\
\text { rationalize the structure of the region's } \\
\text { economy, stimulate the emergence and } \\
\text { development of its new elements, and } \\
\text { contribute to improving the quality of } \\
\text { life of the population. }\end{array}$ \\
\hline I. Shevtsov [11] & $\begin{array}{l}\text { Growth points are territorial systems that } \\
\text { can actively attract investments, generate } \\
\text { scientific and technical and } \\
\text { organizational innovations, use them } \\
\text { effectively, and stimulate the socio- } \\
\text { economic development of cities and } \\
\text { regions. }\end{array}$ \\
\hline $\begin{array}{l}\text { G. Gutman, } \\
\text { A. Myroyedov, } \\
\text { S. Fedin [12] }\end{array}$ & $\begin{array}{l}\text { The point of economic growth is a set of } \\
\text { four elements: } 1 \text { - the territory (as a } \\
\text { component of the country as a whole or } \\
\text { regions within it); } 2 \text { - industry (more } \\
\text { perspective and less expensive for a } \\
\text { specific territory); } 3 \text { - enterprises (basic } \\
\text { for industries or just stable functioning); } \\
4 \text { - programs (aimed at economic } \\
\text { stabilization) }\end{array}$ \\
\hline K. Pavlov [13] & $\begin{array}{l}\text { Economic core is a set of growth poles } \\
\text { and basic elements of the economy }\end{array}$ \\
\hline $\begin{array}{l}\text { M. Svietovtseva } \\
{[14]}\end{array}$ & $\begin{array}{l}\text { The economic core is a complex of } \\
\text { economically interconnected elements, } \\
\text { each of which contributes to the most } \\
\text { efficient functioning of the whole }\end{array}$ \\
\hline G. Potie [15] & $\begin{array}{l}\text { Axis (corridors) of development - } \\
\text { territories located between the poles of } \\
\text { growth, which provide transport } \\
\text { communication and receive additional } \\
\text { impulses of growth due to increased } \\
\text { traffic flow, infrastructure development }\end{array}$ \\
\hline G. Fedoseieva [16] & $\begin{array}{l}\text { Poles of competitiveness imply large } \\
\text { research and production complexes, } \\
\text { which combine the activities of scientific } \\
\text { and research institutes, educational } \\
\text { institutions and high-tech enterprises in } \\
\text { various fields of economy }\end{array}$ \\
\hline B. Gerasimov [17] & $\begin{array}{l}\text { Pre-development zones are territories } \\
\text { that form the main contribution to the } \\
\text { socio-economic development of the } \\
\text { regions, as well as those that determine } \\
\text { its specialization based on the } \\
\text { assessment of competitiveness, potential, } \\
\text { internal and external factors and markets. }\end{array}$ \\
\hline
\end{tabular}


Based on the above-mentioned explanations, we can propose the following logical scheme of their interconnection (Fig. 3).

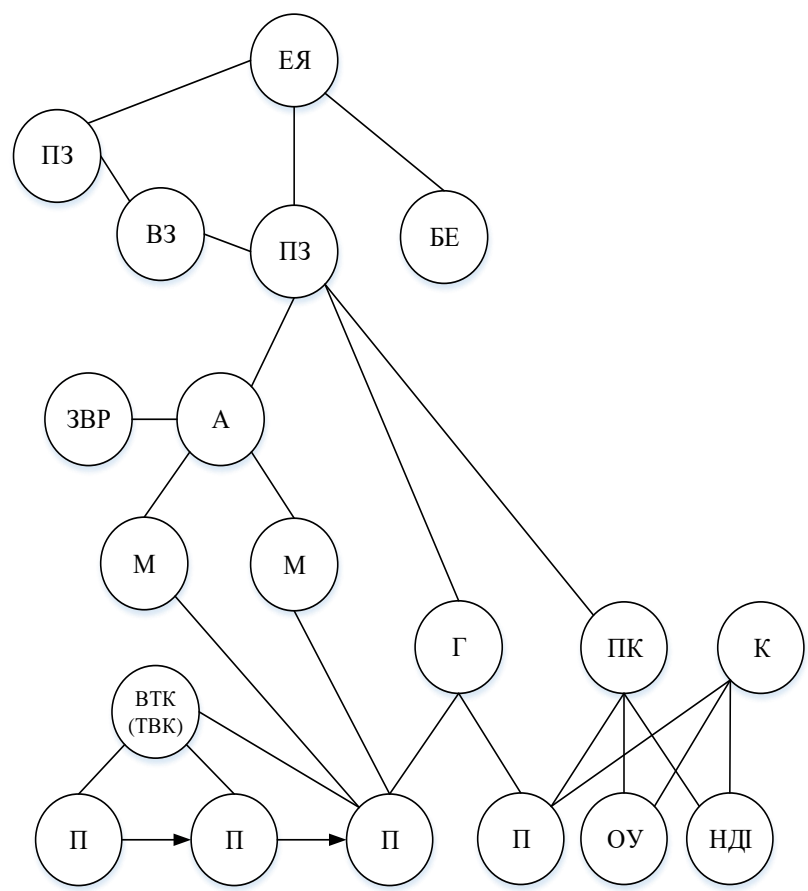

ЕЯ - the economic core; ПЗ - pole of growth; В3 - axis of growth; БЕ basic elements; 3BP - a zone of faster growth; A - agglomeration; M - city; $\Gamma$ - industry; П - enterprise; BTK (TBK) - production-territorial unit (territorial-industrial complex); ПК - the pole of competitiveness; K cluster; ОУ - consecrated institution; НДІ - research institutes.

Fig. 3. Logical scheme of interconnection between some concepts related to the theory of growth

As can be seen from Fig. 3, growth poles in the regions of the country can be both individual enterprises and their aggregate, as a set of industries and a set of cities. At the same time, they should develop dynamically, be propulsive and have a significant influence on the development of others in the region. The definition of points of economic growth (semi-periphery regions) should be carried out with the aid of a two-dimensional matrix in the plane of integral estimation of economic growth factors $\left(\mathrm{I}_{\Phi \mathrm{E} 3}\right)$ - the integral indicator of economic development - GRP per capita $\left(\mathrm{I}_{\mathrm{Ep}}\right)$, which were proposed above (Figure 4). As threshold values $\left(I_{\Phi=3}^{B C}, I_{\Phi=3}^{C}, I_{E p}^{B C} I_{E p}^{C}\right.$ ), which divided the matrix into quadrants, serve respectively serveaverage and above average values integral indicators $\mathrm{I}_{\Phi \mathrm{E} 3}$ and $\mathrm{I}_{\mathrm{Ep}}$.

According to the threshold values, the matrix consists of 9 quadrants that characterize the following state of the regions of the country: 1 - with high potential of factors of economic growth and level of economic development $\left(\mathrm{BI}_{\Phi \mathrm{E} 3}-\mathrm{BI}_{\mathrm{Ep}}\right) ; 2$ - with high potential of factors of economic growth and average level of economic development; 3 - with the average potential of factors of economic growth and high level of economic development $\left(\mathrm{CI}_{\Phi \mathrm{EP}}-\mathrm{BI}_{\mathrm{EP}}\right) ; 4$ - with the average potential of factors of economic growth and level of economic development $\left(\mathrm{CI}_{\Phi \mathrm{EP}}-\mathrm{CI}_{\mathrm{Ep}}\right)$; 5 - with high potential of factors of economic growth and low level of economic development $\left(\mathrm{BI}_{\Phi \mathrm{EP}}-\mathrm{HI}_{\mathrm{Ep}}\right) ; 6$ - with the average potential of factors of economic growth and low level of economic development $\left(\mathrm{CI}_{\Phi \mathrm{EP}}-\mathrm{HI}_{\mathrm{Ep}}\right) ; 7$ - with low potential of factors of economic growth and high level of economic development $\left(\mathrm{HI}_{\Phi \mathrm{EP}}-\right.$ $\left.\mathrm{BI}_{\mathrm{Ep}}\right) ; 8$ - with low potential of factors of economic growth and average level of economic development; 9 - with low potential of factors of economic growth and low level of economic development.

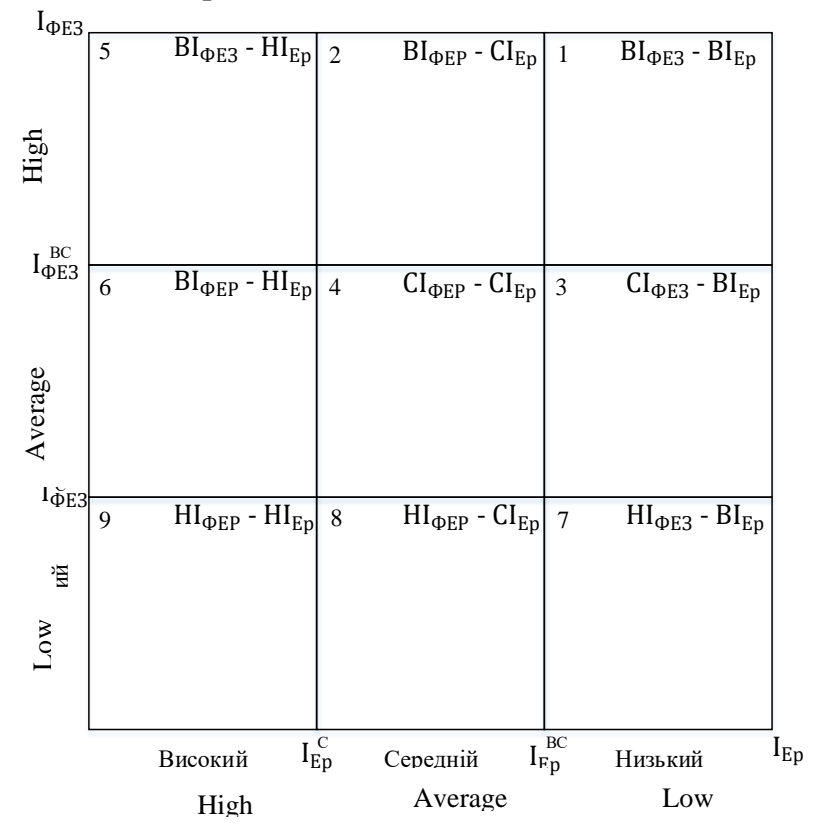

Fig. 4. The matrix of determining the points of economic growth (semiperiphery regions) in the plane "Integral estimates of economic growth and development factors"

According to the calculations conducted, the semiperiphery regions of Ukraine in 2018 in the quadrants of the matrix in the plane "potential of economic growth and level of economic development factors" were distributed as follows (Fig. 5).

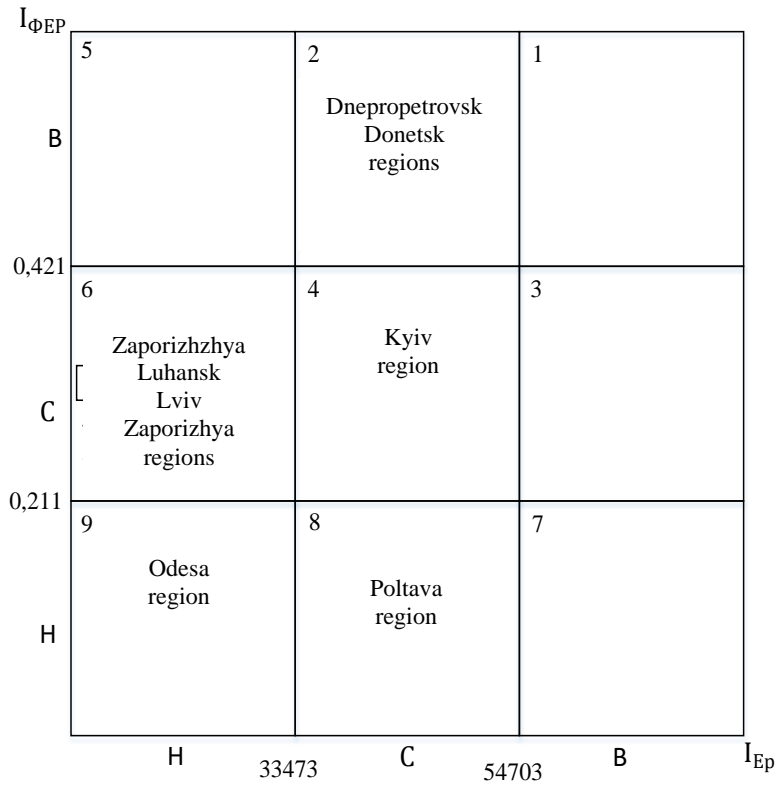

Fig. 5. Distribution of the semi-periphery regions of Ukraine in 2018 in the quadrants of the matrix in the plane "potential of economic growth and level of economic development factors" 
As can be seen from Fig. 5, the following semiperiphery regions of Ukraine are among the points of economic growth: Dnipropetrovsk, Kyiv, Zaporizhzhia, Lviv and Kharkiv regions. Therefore, the priorities of state support for social and economic development should be concentrated in the above regions.

\section{CONCLUSIONS}

Thus, the methodological approach to the comprehensive research of the center and peripheral relations among the regions of Ukraine is substantiated. The peculiarity of the approach in question is implementation of the following interrelated stages: clustering of the regions according to the results of the assessing the factors of economic growth, as well as their economic and social development; the interpretation of the clusters received in terms of their role and place in the center and periphery system.

\section{REFERENCES}

[1] S. Kuznets, Modern Economic Growth. New Haven: Yale University Press 1966.

[2] P. Senisch, The essence and types of economic growth: historical and analytical aspect [Online]. Available: http://irbis-nbuv.gov.ua/cgibin/.../cgiirbis 64.exe?. Accessed on: June 29, 2019

[3] Simkiv L. Ye. "Qualitative economic growth in Ukraine, its assessment and ways to secure it", Innovation economic, no. 2, pp. 23-25, 2014

[4] P. Samuelson, V. Nordhaus. Economics: Textbook allowance, 16-th edition. Moscow: Williams, 2000.

[5] K. Peres, Technological progress and development opportunities as a dynamic goal. Geneva: UNCTAD, 1999.
[6] R. Bade, and M. Parkin, Foundations of Macroeconomics. 4th Edition. Boston: Addison Wesley Higher Education. 2013.

[7] F. Perroux, "Economic Space: Theory and Applications", Quarterly Journal of Economics, vol. 64, pp. 89-104, 1950.

[8] J. R. Boudeville, Les espaces economiques. 3-eme. ed. Paris: Preses Universitaires de france, 1970.

[9] H. R. Lasuen, "Urbanization and Economic Development: Temporary Interactions between Geographic and Industry Clusters", Spatial economics, no. 4, 2009.

[10] T. O. Lascheva, Poles of economic growth as priorities for the development of the region for a strategic perspective: the dissertation of a candidate of economic sciences. St. Petersburg, 2018.

[11] I. S. Shevtsova, and R. E. Rogozina, Economic and social geography of Russia: workshop. - Voronezh : Publishing and Printing Center of Voronezh State University, 2015.

[12] G. V. Gutman, A. A. Miroedov, and S. V. Fedin, Regional Economy Management. Moscow: Finance and statistic, 2001.

[13] K. V. Pavlov, "The economic core of the region: essence, formation criteria and elemental composition", Belarusian Economic Journal, no. 1, pp. 97-109, 2015.

[14] M. G. Svetovtseva, "Management of the formation of the economic core of the region", M.S. thesis, economic sciences. - Voronezh, Russia, 2004

[15] P. Pottier, "Axes de communication et developpement economique", Revue Economique, no. 1, pp. 12-58, 1963.

[16] G. A. Fedoseeva, "Operational experience and state regulation of the activity of special economic zones in France", Socio-economic processes and phenomena, no. 2, pp. 124-130, 2013.

[17] I. V. Chelnokov, B. I. Gerasimova, and V. V. Byikovskij, Regional economy: organizational and economic mechanism for managing regional development resources. Tambov: Publishing House Tambov State Technical University, 2002. 